\title{
Comparative Analysis of Agricultural Entrepreneurship Intentions from a Gender Perspective
}

\author{
Ridha Rizki Novanda ${ }^{1}$, M. Khaliqi ${ }^{2}$ \\ ${ }^{1}$ Faculty of Agriculture, University of Bengkulu, Bengkulu, Indonesia \\ ${ }^{2}$ Faculty of Agriculture, University of Sumatera Utara, Medan, Indonesia \\ ${ }^{*}$ Corresponding author. Email: rrizkin@unib.ac.id
}

\begin{abstract}
Every gender has the right to have the same role in making business happen. In this case, the role of women in the development of the agricultural sector and the Indonesian economy is crucial, not only for men. Business in the agricultural sector is essential to improve in Indonesia. Indonesia is an agricultural country with abundant natural resources. This is a significant potential for Indonesia to develop business in the agricultural sector. The intention of entrepreneurship in the agricultural sector plays a significant role in increasing the entrepreneurial population in the agricultural sector. It is crucial in this study to analyze the factors that influence entrepreneurial intentions in the agricultural sector for men and women. Comparative analysis of entrepreneurial intentions through a gender perspective is the main objective of this study. The collection of data was carried out using a questionnaire, providing respondents with a list of questions via an online questionnaire. Young farmers supported by the Ministry of Agriculture were the respondents in the report. The number of respondents to the study is 190 taken by the census. The data that has been collected is then analyzed quantitatively and with a descriptive approach. Quantitative analysis was performed using a structural equation model-Partial Least Square (SEM-PLS). Based on the data processing results, it was found that only for male entrepreneurs did ATB have a significant impact on entrepreneurial intentions in the agricultural sector. For male and female entrepreneurs, $\mathrm{PBC}$ has no significant impact on entrepreneurial intentions in the agricultural sector. For male and female entrepreneurs, the subjective standard has a significant influence on entrepreneurial intentions in the agricultural sector.
\end{abstract}

\section{Keywords: Agriculture, Entrepreneur, Gender}

\section{INTRODUCTION}

After graduating from university, Indonesia started a change in women's interest in choosing a profession. To become entrepreneurs, many women have career opportunities. Indonesia has 55 million people participating in micro, small and medium-sized enterprises, based on the Women Entrepreneurs in Indonesia study prepared by the World Bank and the Ministry of National Development Planning in 2016. According to data from the Global Entrepreneurship Monitor in 2014, 26 percent of Indonesia's population of 85 million women of productive age are successful entrepreneurs.

The increasing role and involvement of women in the business world is also happening in Indonesia. The role of women in the UMKM sector is generally related to the trade and processing industries such as food stalls, small shops, food processing and the handicraft industry [1]. The development of women entrepreneurs is an interesting phenomenon both from an economic perspective (economic equality) and social equality (social equality), especially in a country that is undergoing a process of political, social and economic transformation. The various notes and facts above indicate that the interest in the entrepreneurial profession is getting higher in various countries, so that research on Entrepreneurial Intentions and its associated with women becomes a fairly new and interesting research issue [2]. In the agricultural sector, especially agribusiness. The creation of new entrepreneurs is significant because Indonesia has great potential in the agribusiness sector [3]. Agribusiness plays a role in the livelihood of most of the population. Not only men can become entrepreneurs in the agribusiness sector, but women can also take on the same role. Until now, women have been able to become entrepreneurs in agriculture to help their partners to support their families [4]. Entrepreneurial women have an understanding role in the family, family members, and the community in increasing economic welfare [5]. The independence factor affects women's decisions to choose entrepreneurship [6,7].

Every gender has the right to have the same role in making business happen. In this case, the role of women in the development of the agricultural sector and the Indonesian economy is crucial, not only for men [8]. Business in the agricultural sector is essential to improve in Indonesia. Indonesia is an agricultural country with abundant natural resources. This is a significant potential for Indonesia to develop business in the agricultural sector. Success in agriculture must be obtained by working 
seriously, understanding market needs and desires, strengthening knowledge of business management, having a consistent entrepreneurial spirit, always following developments in information technology and being able to adapt to very dynamic environments [9].

The intention of entrepreneurship in the agricultural sector plays a significant role in increasing the entrepreneurial population in the agricultural sector [10]. Entrepreneurial intention is a tendency towards a high heart in behavior [11]. Entrepreneurial behavior in the agricultural sector includes agribusiness activities from upstream to downstream. The intention is also the closest attendance of entrepreneurial behavior [12]. It is crucial in this study to analyze the factors that influence entrepreneurial intentions in the agricultural sector for men and women. Comparative analysis of entrepreneurial intentions through a gender perspective is the main objective of this study.

\section{MATERIALS AND METHODS}

Under the guidance of the Ministry of Agriculture, the study was conducted on agricultural entrepreneurs. Because the Ministry of Agriculture is an institution that encourages young farmers in Indonesia, the research location was purposefully selected. The collection of data was carried out using a questionnaire, providing respondents with a list of questions via an online questionnaire. Young farmers supported by the Ministry of Agriculture were the respondents in the report. The number of respondents to the study is 190 taken by the census.

The data that has been collected is then analyzed quantitatively and with a descriptive approach. Descriptive analysis was conducted to determine the characteristics of respondents, dominant intentions and factors that influence the intention to consume vegetables from human waste. Quantitative analysis was performed using a structural equation model-Partial Least Square (SEM-PLS).

This research used theory planned of behavior (TPB). Theory of planned behavior was used as a theoretical basis to see the influence of attitudes on behavior, perceived behavioral control and subjective norms on the intentions of the younger generation in entrepreneurship in the agricultural sector based on a gender perspective.

Descriptive analysis is a method of analyzing the status of groups, individuals, an entity, a collection of circumstances, a thinking pattern or a class of events in the current situation [13]. In order to understand the characteristics of the respondents that are connected to the pattern of the intentions of the respondents, descriptive analysis was chosen.

PLS is an analytical method that can work in the measurement of the variable of action. Purpose is a variable in this analysis that involves an intervening variable. In this analysis, PLS is therefore needed to evaluate the variables that have the most dominant effect. Analysis using PLS has several test phases, according to [14], namely.

a. Outer model analysis
Tests are carried out by checking the Outer model to see the relationship between the indicator block and its latent variables. Second, conduct the validity test with a norm of 0.7 , using loading factors. If a loading factor below 0.7 is present, it must be excluded from the model. Second, the Average Variance Extracted (AVE) value with a threshold of 0.5 is used to analyze the convergent validity value. Third, testing the validity of discriminants. The test consists of comparing the CR value of the AVE square root with the value of the correlation between the constructs. After completing the Outer Model Analysis, the internal model analysis is continued.

b. Inner model analysis

The analysis of the inner model is an analysis that describes the connection between latent variables and other latent variables. Inner model assessment is done by calculating the value of the inner model $(\mathrm{GoF})$, Here is how to compute Gof:

$\begin{array}{ll}\text { Small } & : 0,1 \\ \text { Medium } & : 0,25 \\ \text { Large } & : 0,38\end{array}$

c. Hypothesis testing

The last phase is to test the formulated hypotheses. Hypothesis testing is a test that is performed to see the effect on endogenous latency of exogenous latent variables.

The hypothesis in this study are:

1. ATB (Attitude Toward the Behavior) has a significant effect on entrepreneurial intentions in the agricultural sector for male agricultural entrepreneurs

2. SN (Subjective norm) has a significant effect on entrepreneurial intentions in the agricultural sector for male agricultural entrepreneurs

3. PBC (Perceived Behavioral Control) has a significant effect on entrepreneurial intentions in the agricultural sector for male agricultural entrepreneurs

4. ATB (Attitude Toward the Behavior) has a significant effect on entrepreneurial intentions in the agricultural sector for women agricultural entrepreneurs

5. SN (Subjective norm) has a significant effect on entrepreneurial intentions in the agricultural sector for female agricultural entrepreneurs

6. PBC (Perceived Behavioral Control) has a significant effect on entrepreneurial intentions in the agricultural sector for women agricultural entrepreneurs 
Table 1 The relationship between latent variables and indicators

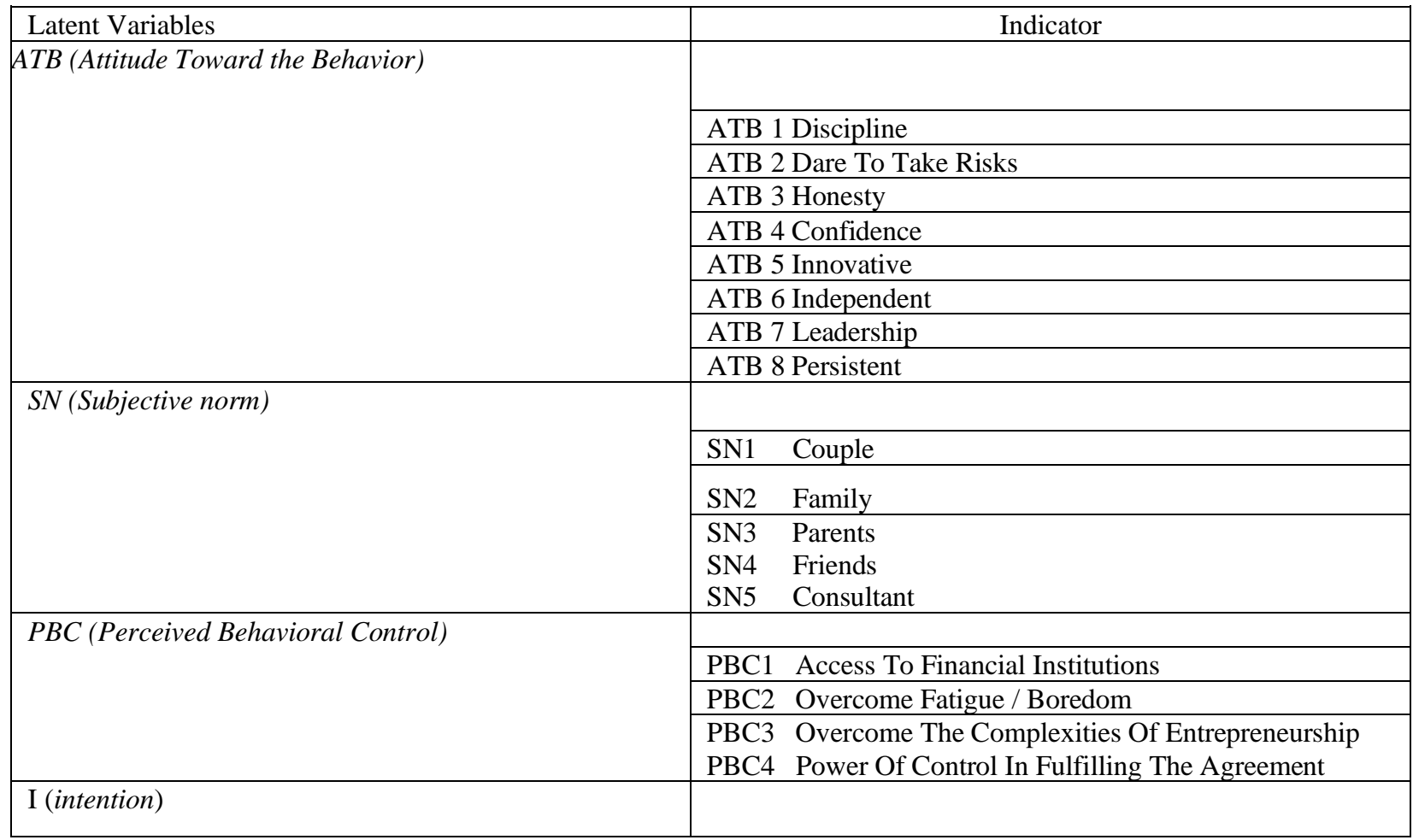

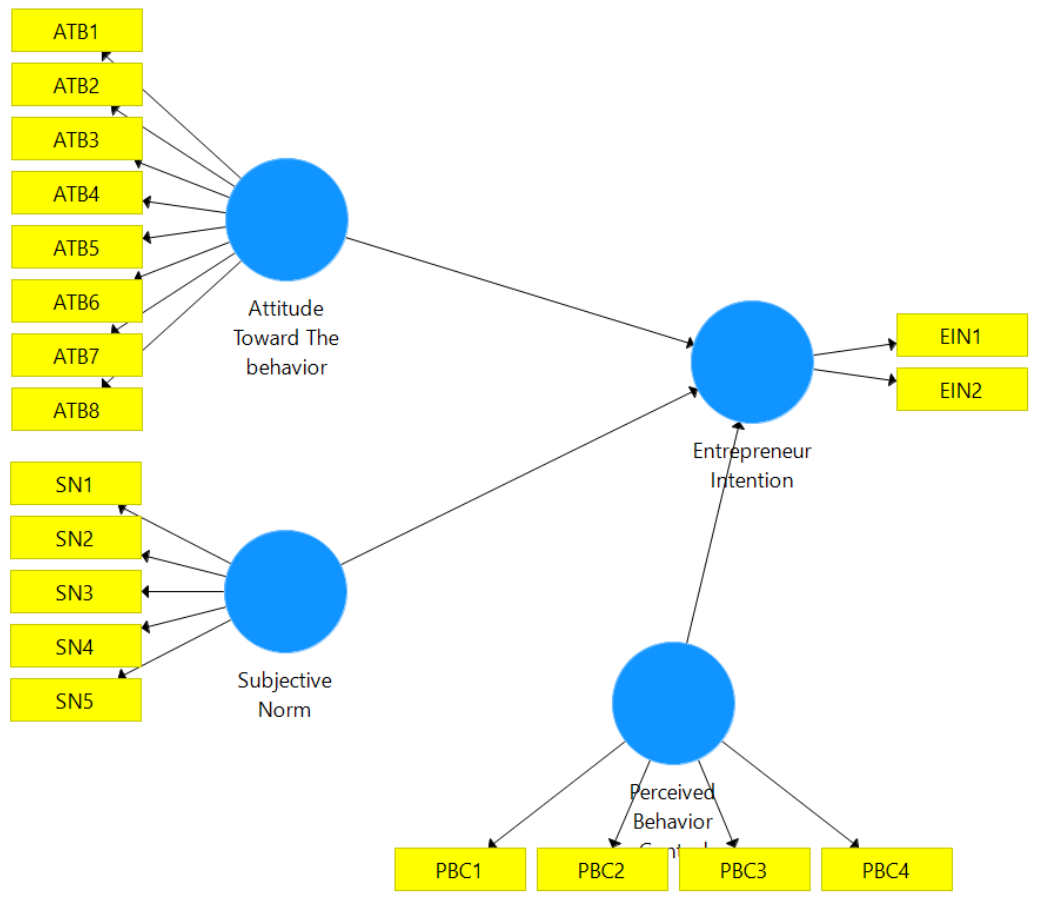

Figure 1 Partial Least Square Model 


\section{RESULTS AND DISCUSSION}

\subsection{Model testing}

The loading factor value is an individual reflective measure that has a standard of 0.7 (14). So that the manifest variable whose value is below 0.7 must be excluded from the model. Based on the research results, the loading factor below 0.7 must be removed from the model. Based on figures 2 and 3, there is a difference between the intention model for male and female agricultural entrepreneurs.

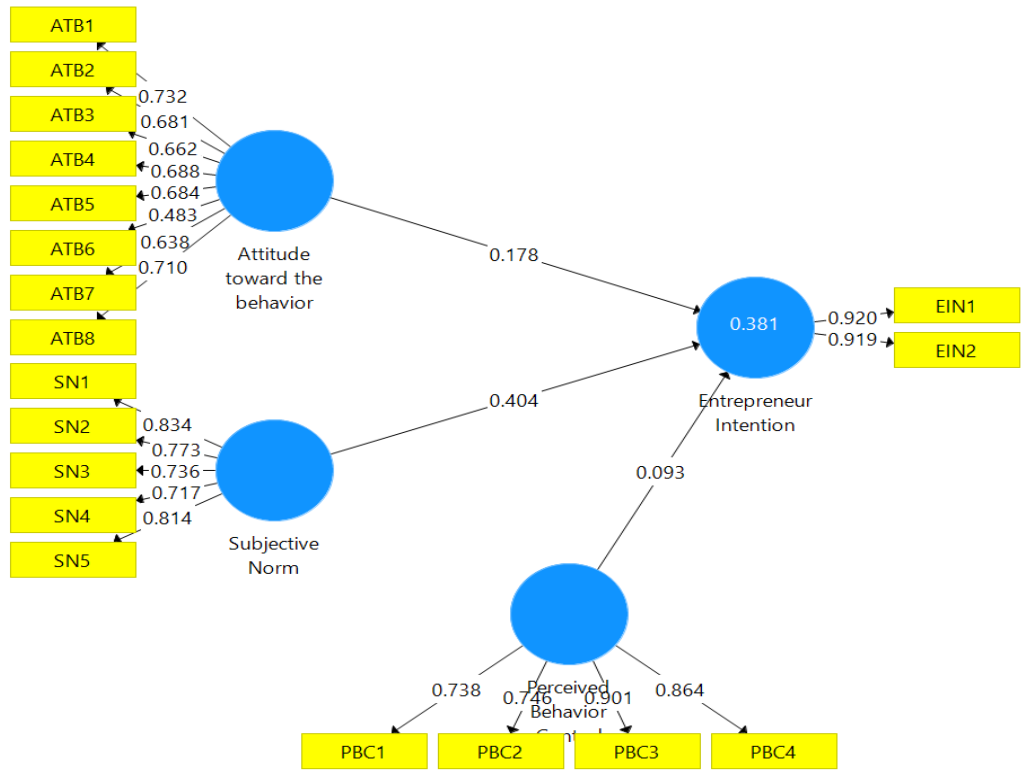

Figure 2 Partial Least Square Model Path Diagram with the Initial Loading Factor of Male Agricultural Entrepreneurial Intention

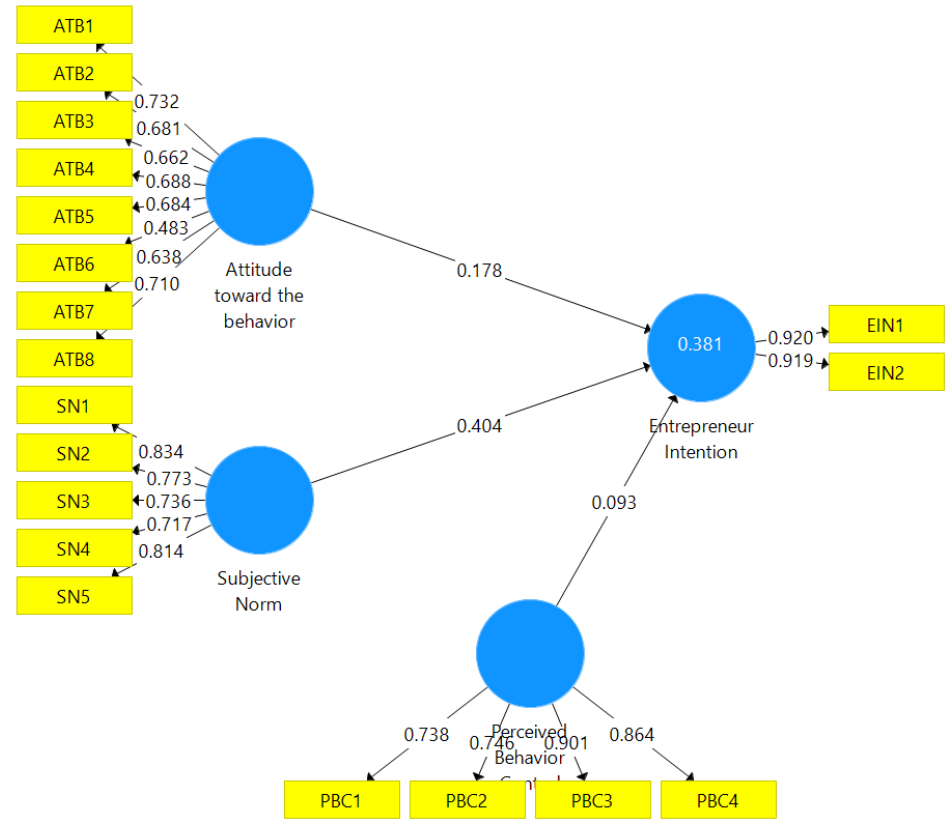

Figure 3 Partial Least Square Model Path Diagram with the Initial Loading Factor of Female Agricultural Entrepreneurial

In the two models in Figure 2 and Figure 3, there are differences from the initial model test. The male model issues indicators ATB3, ATB4, ATB6, ATB7, ATB8 and
PBC1. While the female models issue indicators ATB2, ATB3, ATB4, ATB5, ATB6, ATB7. To produce a perfect path diagram in figure 4 and figure 5 . 


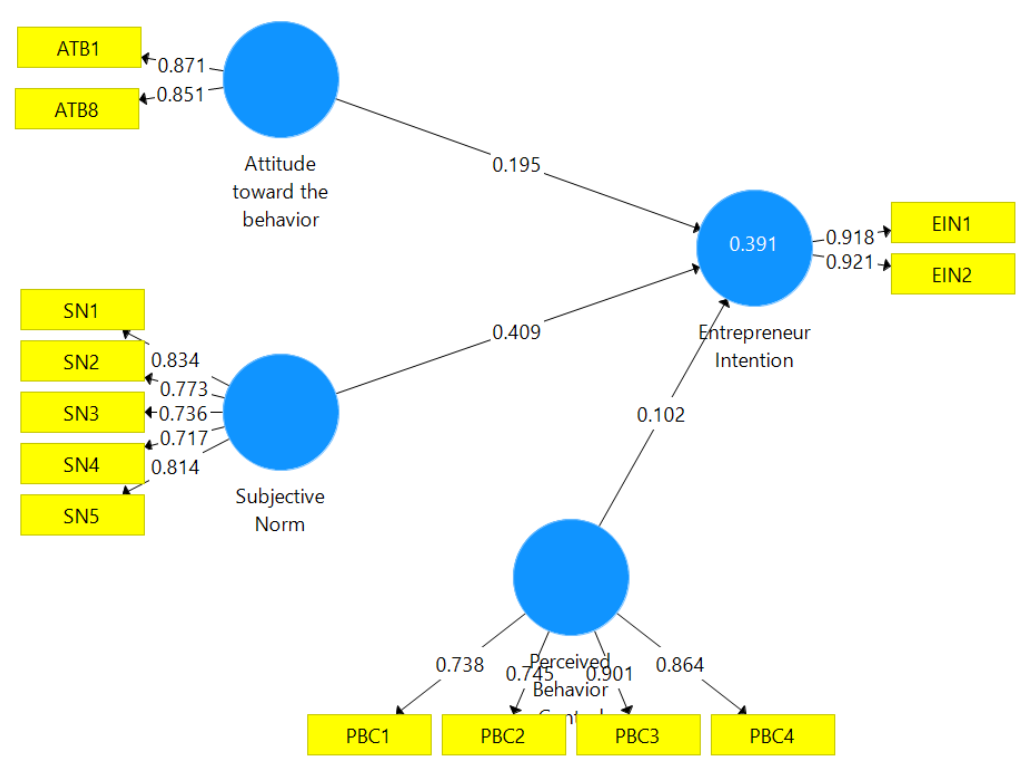

Figure 4 The final model path diagram with loading factor male Model

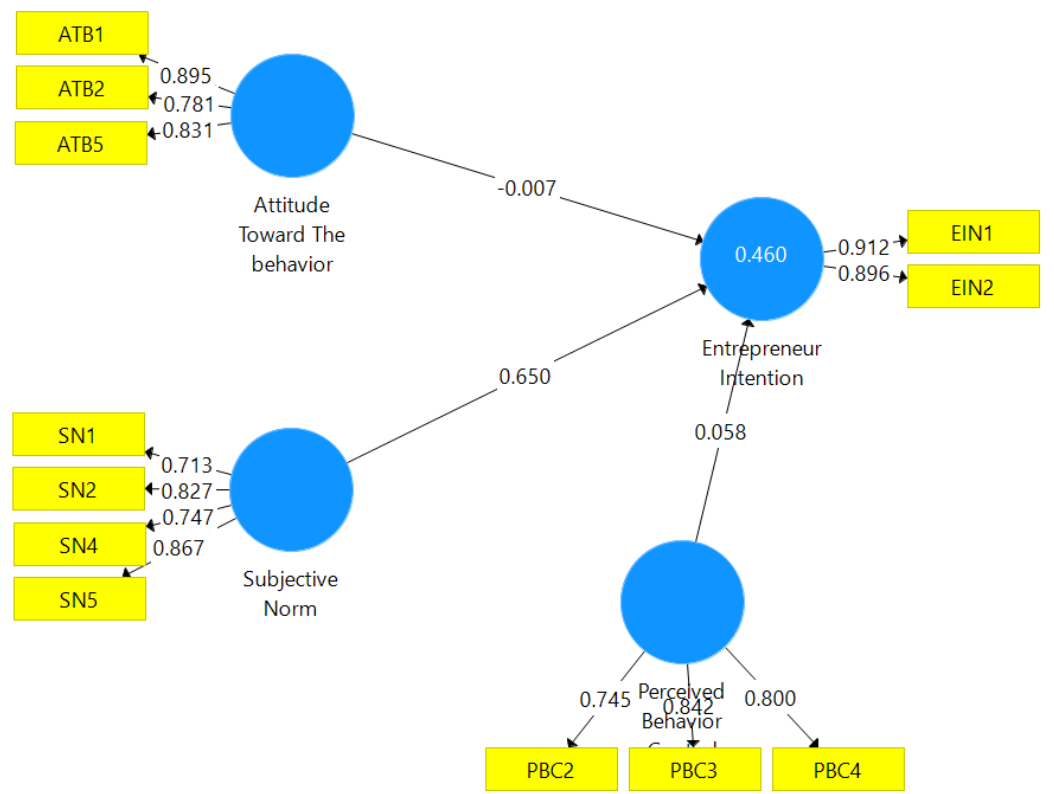

Figure 5 The final model path diagram with loading factor female Model

Build validity is calculated on the basis of the derived average variance (AVE). In this analysis, each models tested, there was no convergent validity problem. The model in its entirety is considered correct. 
Table 2. Average Variance Extracted (AVE) and Composite reability

\begin{tabular}{|l|c|c|c|c|}
\hline \multirow{2}{*}{\multicolumn{1}{|c|}{ Laten variable }} & \multicolumn{2}{|c|}{ Male Model } & \multicolumn{2}{c|}{ Female Model } \\
\cline { 2 - 5 } & Composite reability & AVE & $\begin{array}{c}\text { Composite } \\
\text { reability }\end{array}$ & AVE \\
\hline $\begin{array}{l}\text { Attitude Toward The } \\
\text { behavior }\end{array}$ & 0.852 & 0.742 & 0.875 & 0.701 \\
\hline Entrepreneur Intention & 0.916 & 0.845 & 0.899 & 0.816 \\
\hline $\begin{array}{l}\text { Perceived Behavior } \\
\text { Control }\end{array}$ & 0.887 & 0.665 & 0.839 & 0.635 \\
\hline Subjective Norm & 0.883 & 0.602 & 0.869 & 0.626 \\
\hline
\end{tabular}

Notes : AVE $>0.5=$ Valid Composite Reabiity $>0,6=$ Realible

Build validity is calculated based on the derived average variance (AVE). In this analysis, each construct's AVE value was above 0.5. Hence in the two models tested, there was no convergent validity problem. The model in its entirety is considered correct.

To measure internal consistency, construct reliability is assessed based on composite reliability, and the value must be above 0.6. The overall composite reliability measurement results are above 0.6 or real value, based on Table 2. This means that the information is consistent and capable of explaining the model.

To measure the GoF (Goodness of fit), internal model evaluation can be performed. For the male model, the value of Gof is 0.53 , and for the female model, the value of Gof is 0.57 . In the broad group, both models are included, indicating that the model is fit and suitable for use.

Based on the data processing results, it was found that only for male entrepreneurs did ATB have a significant impact on entrepreneurial intentions in the agricultural sector. For male and female entrepreneurs, PBC has no significant impact on entrepreneurial intentions in the agricultural sector. For male and female entrepreneurs, the subjective standard has a significant influence on entrepreneurial intentions in the agricultural sector.

Table 3. Hypothesis test

\begin{tabular}{|l|c|c|c|c|}
\hline \multicolumn{1}{|c|}{ Male Model } & Standard D & T Statistics & P Values & Explanation \\
\hline ATB->I & 0.087 & 2.241 & 0.025 & Significant \\
\hline PBC->I & 0.087 & 1.180 & 0.239 & Not Significant \\
\hline SN->I & 0.099 & 4.133 & 0.000 & Significant \\
\hline Female Model & & & & Not Significant \\
\hline ATB->I & 0.127 & 0.057 & 0.955 & Not Significant \\
\hline PBC->I & 0.099 & 0.591 & 0.555 & Significant \\
\hline SN->I & 0.139 & 4.675 & 0.000 & \\
\hline
\end{tabular}

Note: $\mathrm{P}$-value $<0.05$ = significant

\subsection{Comparative Analysis of Agricultural Entrepreneurship Intentions from a Gender Perspective}

Based on the measurement results using partial least squares, there are differences between the factors that affect the intention of each gender. Based on the data processing results, it was found that only for male entrepreneurs did ATB have a significant impact on entrepreneurial intentions in the agricultural sector. For male and female entrepreneurs, PBC has no significant impact on entrepreneurial intentions in the agricultural sector. For male and female entrepreneurs, the subjective standard has a significant influence on entrepreneurial intentions in the agricultural sector.

\subsection{Attitude Toward the Behavior (ATB)}

Attitudes towards behavior have a significant effect on male agricultural entrepreneurial intentions. The marker value is 0.025 , with a confidence level of $95 \%$. ATB in the male agricultural entrepreneurial intention model refers to Discipline and Persistent indicators. 
As entrepreneurs in the agricultural sector who have many risks, discipline in entrepreneurship is essential. Entrepreneurs should watch for uncertainty by taking a disciplined approach [15]. The discipline that reflects well a person's responsibility for the tasks assigned to him. Work discipline partially has a positive and significant effect on performance [16]. The discipline of a man was more prominent in the case of this study where a man who runs an agricultural business will improve work ethic. Agricultural products, including products that are difficult to last long. So that the control must have good discipline, male agricultural entrepreneurs strongly believe that discipline is an important indicator.

The indicator that explains the next ATB is persistent. Agricultural entrepreneurs with male gender believe that being persistent is an essential factor in running a business in agriculture. Increasing the behavior of persistence in entrepreneurship will increase business performance [17]. Men tend to believe that being persistent is very important in doing entrepreneurship.

When compared with the female agricultural entrepreneurship intention model, ATB does not have a significant effect on the female agricultural entrepreneurship intention. Attitude is a comprehensive evaluation of concepts carried out by entrepreneurs. An effective system can create an evaluation in the form of emotions, feelings, moods and immediate and direct responses to certain stimuli [18]. The indicators Discipline explains ATB, Dare To Take Risks, and Innovative. This shows that Discipline, Dare To Take Risks, and Innovative do not affect women's agricultural entrepreneurial intentions.

\subsection{Subjective Norm (SN)}

The subjective norm is defined as the confidence of an individual in the norm, the people around him and the motivation of the individual to obey these norms. There are two key aspects of subjective norms, namely: belief in perceptions, expectations of reference norms, the views of other parties that are deemed important by people who recommend that individuals display such behavior or not, as well as incentive for individual willingness to carry out the opinions or thoughts of parties or not to carry them out. Others who think it is crucial that people should or should not behave [19]. Based on the results of the measurement, it was found that SN had a substantial influence on male and female agricultural entrepreneurs' intentions. Similar to research conducted by [20][21][22] which states that factor influences entrepreneurial intentions in the agricultural sector.

Indicators of Couples, Families, Parents, Colleagues, and Consultants describe SN. The high expectations for progress are explained by the five indicators. Spouses give agricultural entrepreneurs leverage to continue their business. The main explanation for entrepreneurship is the financial situation with a partner. The fulfilment of the wishes of your partner is a tremendous responsibility.

Families have a big influence in fostering entrepreneurial intentions in the agricultural sector. Family support and entrepreneurial personality have a significant positive effect on entrepreneurial intentions. Entrepreneurial personality shows a more dominant influence on entrepreneurial intentions than family support [23]. Family is very important in choosing an entrepreneurial career. Entrepreneurship in the agricultural sector is not easy. There are many oblique assumptions from the community that agriculture is not promising. So the biggest challenge is convincing families to become entrepreneurs in the agricultural sector. In the family there are parents who have a strong influence in career choices. There is a very significant negative relationship between perceptions of parental support and career decision making. , the more positive one's perception of parental support, the lower the difficulty felt in making career decisions [24].

\subsection{Perceived Behavior Control}

Based on the measurement results, Perceived Behavior Control has no significant effect on entrepreneurial intentions in the agricultural sector for men and women. The absence of the effect of perceived behavior control means that the perceived ease or difficulty of carrying out the behavior. This is in line with several studies conducted in the entrepreneurial sector in the agricultural sector which considers entrepreneurial intentions in the agricultural sector not supported by perceived ease or difficulty to perform behaviour [20] [25] [26].

\section{CONCLUSION}

Based on the data processing results, it was found that only for male entrepreneurs did ATB have a significant impact on entrepreneurial intentions in the agricultural sector. For male and female entrepreneurs, PBC has no significant impact on entrepreneurial intentions in the agricultural sector. For male and female entrepreneurs, the subjective standard has a significant influence on entrepreneurial intentions in the agricultural sector.

\section{REFERENCES}

[1] Sari S, Priatna WB, Burhanuddin B. "Pengaruh Aktivitas Wanita Wirausaha Terhadap Pertumbuhan Usaha Olahan Kentang di Kabupaten Kerinci", Jambi. J Agribisnis Indones. 2017;3(1):39.

[2] Jati W. "Analisis Motivasi Wirausaha Perempuan (Wirausahawati) Di Kota Malang". J Humanit. 2009;4(2):11507.

[3] Saragih B. "Pembangunan Sistem Agribisnis Di Indonesia Dan Peranan Public Relation". SOCA Socioecon Agric Agribus. 2001;

[4] Nainggolan DY. "Perempuan Muda Pada Rumah Tangga Miskin", Di. Perspektif. 2013;6(April):14 29.

[5] Sayekti NS, Agustin W. Nugrahaeni Suci Sayekti. "J Penelit Ekon dan Akunt". 2016;I(3):245-64. 
[6]Sehani S. "Faktor-Faktor Yang Mempengaruhi Keputusan Perempuan Memilih Berwirausaha (Studi Kasus Pada Penjahit Pakaian di Kecamatan Tampan - Pekanbaru)". Marwah J Perempuan, Agama dan Jender [Internet]. 2010 Nov 2;9(2):160. Available from: http://ejournal.uin suska.ac.id/index.php/marwah/article/view/479

[7] Rizal M, Setianingsih D, Chandra R. "Faktor-faktor yang Mempengaruhi Wanita Berwirausaha (Studi Kasus di Kota Langsa)". J Manaj dan Keuang Unsam. 2016;5(2):525-34.

[8] Arsanti TA. "Perempuan dan Pembangunan Sektor Pertanian. J Maksipreneur Manajemen, Koperasi, dan Entrep". 2013;3(1):63.

[9] Mukti GW, Budi Kusumo RA, Qanti SR. "Perilaku Sukses Petani Muda Wirausaha Lulusan Fakultas Pertanian Universitas Padjadjaran". J Agribisnis Terpadu. 2017;10(2):221.

[10. Ridha RN, Wahyu BP. "Entrepreneurship intention in agricultural sector of young generation in Indonesia". Asia Pacific J Innov Entrep. 2017;

[11. Ajzen I. Ajzen, I. (1991). "The theory of planned behavior. Organizational Behavior and Human Decision Processes.The theory of planned behavior". Organizational Behavior and Human Decision Processes. 1991.

[12] Ajzen I. "From Intentions to Actions: A Theory of Planned Behavior". In: Action Control. 1985.

[13] Moh. Nazir. "Metode Penelitian". Metod Penelit. 2014;

[14] Ghozali I. "Model Persamaan Struktural". Konsep dan Aplikasi Dengan Program AMOS 24.0. Update Bayesian SEM. In: Model Persamaan Struktural Konsep dan Aplikasi Dengan Program AMOS 24 Update Bayesian SEM. 2017.

[15] Sull DN. "Disciplined entrepreneurship". MIT Sloan Management Review. 2004.

[16] Amril. "Pengaruh Disiplin Kerja Dan Gaya Kepemimpinan Terhadap Kinerja Karyawan". J Kewiraushaan. 2017;3(2):50-8.

[17] Nursiah T, Kusnadi N, Burhanuddin B. "Perilaku Kewirausahaan pada Usaha Mikro Kecil (UMK) Tempe di Bogor Jawa Barat". J Agribisnis Indones. 2017;

[18] Anggelina J, Dan JP, Japarianto E. "Analisis
Pengaruh Sikap, Subjective Norm dan Perceived Behavioral Control Terhadap Purchase Intention Pelanggan SOGO Department Store di Tunjungan Plaza Surabaya". Jurnal Strategi Pemasaran. 2014.

[19] Ajzen I. "The theory of planned behaviour: Reactions and reflections". Psychology and Health. 2011.

[20] Ridha RN, Burhanuddin B, Wahyu BP. "Entrepreneurship intention in agricultural sector of young generation in Indonesia". Asia Pacific J Innov Entrep [Internet]. 2017 Apr 3;11(1):76-89. Available from: https://www.emerald.com/insight/content/doi/10.1 108/APJIE-04-2017-022/full/html

[21] Muhammad AD, Aliyu S, Ahmed S. "Entreprenuerial Intention Among Nigerian University Students". Am J Bus Educ [Internet]. 2015 Oct 1;8(4):239. Available from: https://clutejournals.com/index.php/AJBE/article/ view/9419

[22] Peter Schmidt, Tatarko. "EntrepreneurialIntention and Values: Results from a Russian Population Survey". Psychol J High Sch Econ [Internet]. 2016 Jun 30;13(2):240-55. Available from: https://psyjournal.hse.ru/en/2016-13-2/186648946.html

[23] Setiabudi kezia jade. "Terhadap Niat Berwirausaha Mahasiswa Program Studi Manajemen Terakreditasi “ A " Pada Perguruan Tinggi Swasta Di Kota Surabaya". AGORA. 2019;7(1):1-6.

[24] Islamadina EF, Yulianti A. "Persepsi Terhadap Dukungan Orangtua dan Kesulitan Pengambilan Keputusan Karir Pada Remaja Perceptions of Parental Support and Career Decision-Making Difficulties In Adolescents". J Psikol. 2005;12(1999):33-8.

[25] Shiri N, Mohammadi D, Mahmoud Hosseini S. "Entrepreneurial Intention of Agricultural Students: Effects of Role Model, Social Support, Social Norms and Perceived Desirability". Sch Res Libr Arch Appl Sci Res. 2012;4(2):892-7.

[26] Ambad SNA, Damit DHDA. "Determinants of Entrepreneurial Intention Among Undergraduate Students in Malaysia". Procedia Econ Financ, 2016. 